\title{
The Operation of the Low Pay Commission
}

\author{
William Brown \\ Montague Burton Professor of Industrial Relations
}

\begin{abstract}
$\underline{\text { Abstract }}$
The paper provides an account of the working of the Low Pay Commission that was established to advise on the introduction of a statutory National Minimum Wage for the United Kingdom. It discusses the way in which the Commission was constituted and the consultation procedures and research methods it developed over its first four years. An account is provided of the principles the Commission developed and of the problems that had to be overcome in delivering what proved to be a successful labour market intervention
\end{abstract}

\section{$\underline{\text { JEL Classification }}$}

J. 58

\section{Keywords}

Minimum wages, social partnership, low pay 


\section{The Operation of the Low Pay Commission \\ William Brown \\ Montague Burton Professor of Industrial Relations}

\section{Introduction}

The National Minimum Wage was the Ugly Duckling of the 1997 Labour Government. The proposal had been a favourite target of Conservative attack during the election campaign, with blood-chilling predictions of its unemployment implications. The Labour leadership's response had been nervously defensive. The commitment to a statutory minimum wage had been forced on them by Party Conference and it threatened to undermine their prime objectives of winning business confidence and reducing unemployment. But by the 2001 election all this had changed. What was once seen as a risky concession to Old Labour was being presented as a major achievement of New Labour's first government. It was, furthermore, an innovation to which the Conservative Party had been converted.

The task of turning this awkward pledge into a workable policy was given to a new body, the Low Pay Commission. This account describes how the Commission set about its work, and how it tackled the issues that emerged. It deals with the design of the National Minimum Wage, its introduction, and the monitoring of its initial impact up to the 2001 General Election, by which time the Wage could be considered soundly established. An official account of its work is to be found in the Commission's first three reports (LPC, 1998; 2000a; 2001a,b). The present paper is a personal, Commissioner's eye view of the process, comparable with earlier accounts by Bain (1999) and Metcalf (1999a; 1999b) but taking it over a longer period.

\section{The Nature of the Commission}

The Low Pay Commission was established in July 1997, within three months of Labour's election. It was one of the first bodies set up under the Nolan Committee's principles requiring open advertisement and independent assessors. Important to its later 
functioning was its relatively small size of just nine Commissioners, balanced between three people with a trade union background, three with an employer background, and three academic labour relations specialists. The trade union members consisted of the General Secretary of the clothing union KFAT, the Chief Economist (replaced, when he became Chair of the Health and Safety Commission, by the Head of Economic and Social Affairs) of the Trades Union Congress, and a member of the union UNISON's Executive (replaced, when she became Chair of ACAS, by the Deputy General Secretary of the union TGWU). The employer members were the Human Resources Director of a major hotel and catering group, the Human Resources Policy Director (later promoted to Deputy Director-General) of the Confederation of British Industry, and the Chief Executive of a retailers' federation (replaced on retirement by the Chief Executive of a bakers' federation). The Commission Chair was one of the academics, George Bain, then Vice Chancellor of Queen's University, Belfast, and previously Principal of the London Business School, with considerable experience as an arbitrator.

The Commission's task was to make recommendations on the Minimum Wage to Government. For these to have credibility it was important that they should have legitimacy in the eyes of both organised labour and employers. The Commissioners were, and perceived themselves to be, engaged in an exercise in social partnership. This meant that the TUC and CBI were consulted on their appointment. But each Commissioner served as an individual, without mandate or requirement to report back. They were also self-consciously independent of Government, which was reflected in a robust collective resistance to any whiff of political pressure. In practice they rarely divided on simple interest-related lines. For example, some of the toughest questioning of the views of small business people came from the Commissioners from just that background. Indeed, of the many issues on which the Commission was required to reach agreement, only two created a clear split between employers and trade unionists. The first of these was the question of whether there should be a separate rate for young people, to which we shall return. The second was the predictable issue of the actual level of the Wage, and of the size of its subsequent uprating. On these occasions the Chair mediated, over the course of 
a couple of days of meetings and side-meetings, a fairly conventional, if unusually wellinformed, bargain.

Supporting the Commission was a strong secretariat that varied between about ten and twenty people according to need. Although situated in the Department of Trade and Industry, it drew its specialists on training, social security, statistics and so on from other relevant departments. Their tasks covered gathering and processing evidence, arranging consultative visits and hearings, conducting surveys and statistical and economic analyses, and drafting the Commission's bulky reports. They also managed what was to become a large programme of commissioned research.

Another substantial support for the Commission was the National Minimum Wage Act, passed in 1998. This was a strong measure, reflecting the long-standing commitment to the National Minimum Wage of Ian McCartney, the Government minister who steered it through Parliament. Its broad definition of an eligible employee, for example, encompassed home-workers, agency workers, casual labourers, workers on short-term contracts, and many of those spuriously defined as 'self-employed'. The Act placed the burden on employers to keep the necessary records to prove that they were paying the Wage, rather than requiring aggrieved employees to prove that they were not. As well as giving workers the right to recover any underpayment due to them, it provided for substantial penalties, with fines of up to $£ 5000$ for each offence, for refusal to pay the Minimum Wage, for having inadequate or inaccurate records, and for obstructing enforcement. The task of enforcement was later given, on the recommendation of the Commission, to the Inland Revenue which tackled the task with energy, imagination and common sense.

The Government also simplified the Commission's task by prejudging certain aspects of the National Minimum Wage. Particularly important was that it should be a common minimum across the whole UK, not subject to regional variations (as in Japan or Canada, for example) nor to sectoral variations (as had been the Wages Council system). If given the option, it is likely that the Commission would have come to the same conclusion. 
Low pay is very sectorally specific, and also localised within geographical areas much smaller than the conventional economic regions. Furthermore those representing the more depressed regions were themselves wary lest the recognition of regional variations in living costs through regional variations in statutory minimum wages might have other adverse consequences, such as inferior economic status or regional variations in benefit entitlements.

More generally, the Commission's terms of reference studiously avoided any suggestion that the Minimum Wage should be set at a level to represent some sort of acceptable living standard. An important fiscal motivation for a statutory minimum wage was the fact that, without any floor to wages, ever more low-paid employees with families were becoming entitled to means-tested in-work benefits, at ever-increasing cost to the Exchequer. The benefits system was in effect subsidising low-paying employers. The National Minimum Wage was thus an essential component in making viable the Government's ambitious strategy of reforming the tax and benefit system in order to encourage the jobless back into work and to reduce family poverty. The question of a decent living standard was being addressed through the whole package around Working Family Tax Credits of which the National Minimum Wage was a part, and not through the National Minimum Wage alone.

\section{The task}

The remit of the Low Pay Commission has been to implement a single labour market innovation, and to maintain it indefinitely. This narrow focus but long-term responsibility has been important for the way in which the Commission has functioned. Unlike many public enquiries, the key question has not been what should be done, but how it might be done best. And it has not been a matter of the key interest groups having a single opportunity to give their points of view, but of their having recurring opportunities to do so, as experience develops.

For these reasons, the Commission placed less emphasis than is normal on the formal procedures of seeking evidence and holding hearings. A great deal of initial evidence was 
received, and hearings were held with some of the more substantial interest groups. But although many commented on what they considered to be an acceptable level for the Minimum Wage, no-one was in a position to provide hard evidence on the potential impact of different levels of it. Even the Government's own formal evidence amounted largely to a review of published research, the most telling of which concerned findings on minimum wage increases in other countries.

The paradox was that for this quintessentially economic question - what would be the impact of a minimum wage - economic analysis had no useful answer. Or rather, it suggested a range of answers, but not where in that range any given minimum rate might be appropriate. The outcomes suggested by theory were fundamental to the success of the project, and they covered a range of sensitive issues. At what level would a minimum wage begin to cause significant job loss? How far would an increase in rates of pay for low paid jobs encourage the economically inactive to enter employment? Would more competitive firms pick up the market share and employ the laid off labour from firms forced out of business by the minimum rate? How far would employers who were forced to pay more find it worthwhile to invest more in training and equipment to raise their labour's productivity? How far would they be managerially capable of responding in this way? Would a pressure to reassert pay differentials within firms dramatically amplify the labour cost consequences of the introduction of a minimum wage? Would the inflationary implications of such a response prompt the Monetary Policy Committee to take preemptive measures on interest rates that would themselves increase unemployment? How far would a minimum wage discriminate against young workers? It was evident that there would be no straight-forward answer to any of these big questions. The answers would vary substantially by sector, as well as by the phase in the business cycle.

\section{Consultation}

The Commission quickly decided that their best way of gaining insights on these questions was by going out and meeting the data. That is, that only by talking to the low payers and the low paid at their workplaces could they gain a rounded view of the salient issues sector by sector. They therefore embarked upon, and continue to maintain, a 
programme of day trips, sometimes incorporating over-night stays and routine Commission meetings, throughout the United Kingdom. During the course of these, two or three Commissioners, accompanied by one or two secretariat members, might, for example, meet a group of care home owners, visit a sausage factory, visit a motorway service station, and meet a group concerned with placing people with disabilities in employment. Particular efforts were made to talk to examples of firms where difficulties with the Minimum Wage were expected or reported. But it was also helpful to meet examples of employers in vulnerable sectors for whom the Minimum Wage offered no challenge. It became evident early on that, especially among small firms, a dependence on low pay rates as a means of competition is often associated with very poor labour management.

Initially the Commission's consultations, whatever the sector, were concerned with a fairly long check-list of questions. These included: the composition of the pay-packet for the low paid; the nature and sensitivity of any incentive schemes; the use of overtime; who would benefit and how much they would gain; possible knock-on effects on differentials; training potential; scope for improving productivity through better equipment; labour turnover; and recruitment problems. Then there were questions specific to particular sectors, such as those concerned with casual labour in agriculture, tipping in restaurants, subsidised accommodation in hotels, staff discounts in retailing, and overseas competition in clothing. A fruitful opening to a discussion of enforcement was often to ask what methods the firm thought that its rivals might use to cheat on the Minimum Wage. And it was always interesting to ask how firms might cope, if at all, with a selection of possible Minimum Wage rates.

Once the Minimum Wage had become law the issues discussed shifted to how firms were actually coping with it and how it had changed their labour market. A number of sectors raised complaints that were discussed in situ and in some cases led to changes in the regulations and in some cases led to changes in firms payment procedures. For example, exceptions were made to exclude people who receive 'pocket money' while staying in religious communities. But they were not made for the young people who act as 
supervisors at 'activity holiday' camps, largely in return for bed and board. Later still the emphasis of consultation has shifted to some of the more difficult issues to do with enforcement in, for example, the 'black economy', and among ethnic communities where language barriers and other disadvantages may create market aberrations.

Enforcement has been a central issue from the start. The great majority of workers likely to be affected by the Minimum Wage are in private services which, though intensely competitive domestically, are unaffected by foreign competition. What matters to lawabiding firms in these sectors is that none of their rivals should gain a competitive cost advantage by cheating on the Minimum Wage. Employers have generally had very little objection in principle to the idea of a statutory minimum. Many sectors had relatively recent benign experience of it under Wages Councils. Those that had not, such as security, care homes, and industrial cleaning, could see benefits in some order being brought to their labour markets. The main concerns that those employers who were affected expressed to the Commission were, first, that the level of the rate should be manageable and, second, that their domestic competitors should be forced to comply.

The Commission's programme of consultation has had an important political as well as informative function. So far as external relations have been concerned, it has been of inestimable value that national representatives of many interest groups have known that Commissioners have made an effort to meet their grass-roots members and to understand the complexities of their complaints. Itineraries have been planned with the assistance of organisations such as Citizens Advice Bureaux, Chambers of Commerce, Low Pay Units, and the Federation of Small Business, each suggesting interviews to make particular, valuable, points. The visits have enlivened the Commission's continuing dialogue with those affected by the Minimum Wage.

Perhaps less obvious has been the effect of the consultation process upon relations within the Commission. The richness of experience associated with interviewing the low payers and low paid on their home ground established a vivid and shared set of reference points on a myriad of aspects of the Minimum Wage. The visits, and subsequent discussion of 
them among Commissioners, have done more than anything else to increase understanding of the complexity of the low pay problem and to prevent simple stereotyping. It should also be acknowledged that there has been a significant emotional contribution from many visits. From first-hand accounts by, for example, home-workers, multiple job-holding cleaners, and sweat-shop employees, Commissioners have gained an acute awareness of the utter vulnerability of so many people at the bottom of an unregulated labour market. The experience has undoubtedly increased their determination to make the National Minimum Wage work.

Another aspect of consultation was within what might be broadly described as government. Quite apart from the usual network of communication between officials characteristic of the Civil Service, Commissioners themselves met relevant bodies to share views and pre-empt misunderstandings. One important meeting, just after the publication of the Commission's First Report, was with the Bank of England's Monetary Policy Committee. This gave a chance for Commission members to discuss the reasoning behind their recommendations and, in particular, their view that the introduction of the National Minimum Wage would have minimal 'knock-on' effects on the economy through attempts to restore pay differentials. Later, another presentation to the MPC provided an opportunity to discuss evidence on the actual impact of the Wage. Useful meetings were held later on with senior Treasury officials on the relationship between the National Minimum Wage and the broader tax and benefit strategy. Statistical problems and requirements were discussed at meetings with senior officials of the Office of National Statistics (ONS). Although there was never any question of seeking Government approval for the Commission's decisions, it helped for the Chair of the Commission to make the relevant case in person to the Secretary of State or Prime Minister when reports were submitted. From the start and at all levels, the Commission has gone out of its way to talk to people in its efforts to avoid misunderstanding. Partly as a result, the Government has very largely accepted their recommendations.

\section{$\underline{\text { Research }}$}


As well as its visits, the Commission also built up a substantial programme of more conventional research (LPC, 2000b). A relatively small but important part was carried out 'in house'. A 'before and after' postal survey was conducted of several thousand small employers in affected sectors with the help of trade associations. This was particularly helpful in obtaining information on the way that businesses had met the shock to their costs of paying the Minimum Wage. Otherwise, the relatively few months within which the First Report had to be produced provided little opportunity for research in anticipation of the Wage. But considerable thought was given to research on the manner in which the Wage then impacted upon firms, workers and the economy, and each subsequent report has been informed by around twenty specially commissioned projects typically costing just a few thousand pounds each. Some of these have been carried out by groups with unique access to the low paid, such as Citizens Advice Bureaux and Low Pay Units. Some work has been done by labour market consultancy firms with their specialised surveying experience. Much has been done by academics with expert knowledge of particular sectors and statistical sources. The Commission deliberately encouraged a wide variety of research methodologies, from case studies and observation through to simulation and complex statistical analysis, and some of Britain's outstanding labour market scholars have produced seminal studies as a result. The 'natural experiment' aspect of introducing a minimum wage has been very fruitfully exploited.

There was, however, one vital area of information that was seriously defective, and the gravity of its defects became increasingly apparent as the Commission's work progressed. The official statistics on earnings, upon which were based all estimates of the number of people affected by and the cost of the National Minimum Wage, were inadequate. Britain has two main regular sources of earnings data. The annual New Earnings Survey (NES) samples from the payroll records of employees who pay income tax by PAYE. It was devised in the 1960s when incomes policies focussed attention on the more unionised sectors of the workforce. It is accurate so far as the pay and hours of those sampled, but misses many low-paid employees, particularly young people and parttimers, who do not pay tax, and thus understates the low paid. The other source is the rolling Labour Force Survey (LFS), which relies on the recollections of interviewees on 
the doorstep (or of their partners) on a wide range of labour market characteristics. Interviewees' accounts of earnings are often vague, and since they tend to overstate their hours, the LFS tends to under-calculate low pay in hourly earnings terms. Aware of these broad defects, but unable to assess the more unsystematic biases, the ONS produced a Central Estimate of the two series (ONS, 1998). But since for the low paid this was, to put it crudely, the average of two incorrect series, it provided a poor source of guidance. The Commission pressed a receptive ONS to remedy the faults in these vital sources (LPC, 1999). This contributed to bringing about a general review of labour market statistics (ONS, 2002), but for the foreseeable future representative statistical knowledge of low pay remains very inadequate.

Meanwhile, the Commissioners had to deal with the difficulty that they were, in effect, sailing with an ever-changing statistical chart as the ONS endeavoured to sharpen up its Central Estimate series. They decided to adopt a policy of complete candour, and to revise their estimates in the light of the best available data. Thus the First Report predicted that 'around two million people' would benefit immediately from the National Minimum Wage (LPC, 1998: 5). The Second Report had to revise this to 'well over 1.5 million workers were entitled to higher pay' (LPC, 2000a; 16). By their Third Report, after further discussion of the vagaries of the official data sources, they concluded that 'workers in around 1.3 million jobs were entitled to higher pay' (LPC, 2001; 22). Perhaps because of the policy of candour, perhaps because the revisions have been downwards, there has been little adverse criticism of the Commission arising from these wayward data.

\section{Principles and practice}

Two of the guiding principles that the Commission steered by have already been discussed: widespread consultation and careful research. Another one adopted early was 'keep it simple': the view that any avoidable complications would impede understanding of and compliance with the National Minimum Wage. This applied particularly to the technically complex task of defining the Wage. Whether, that is, it should include overtime, shift payments, pension contributions, bonuses, piecework earnings, tips, 
accommodation allowances, subsidised meals, and so on. The visits proved invaluable in hammering out these issues. It emerged, for example, that the very low paid rarely benefit from additional payments, and that for most, being part-time workers, overtime is unknown. Simplicity of definition has proved robust in practice.

A far more contentious issue was that of whether young workers should have a lower Minimum Wage rate than 'adult' workers. A complexity of political and statistical issues generated considerable difficulties within the Commission. The Government's evidence made clear its concern that the National Minimum Wage should not jeopardise its objective of reducing youth unemployment. It pointed to research that showed not only that young people were more vulnerable to being unemployed than older people, but also that their life-chances were more damaged by unemployment. It also emphasised the evidence from other countries that sometimes showed minimum wages having adverse employment consequences for young people. The TUC was firmly of the view that there should be no discrimination in pay by age for workers of 18 or over doing the same job. Its major affiliated unions were bound by conference resolutions to this effect. Employers pointed out that, in practice, use of age-for-wage scales was rapidly diminishing, but also that on average young workers' earnings do rise steeply towards the overall average from the mid-teens to the early twenties. The Commission's statisticians were to show that much of this age effect did not reflect employer practice as such, but the fact that young people migrate into better-paid sectors as they grow older. There was endless scope for debate as to whether young workers' low pay reflected lower productivity, or inexperience, or employer prejudice, or lack of training, or job searching, and so on. But that did not resolve the disagreement within the Commission.

In the end it was resolved by a creative compromise. There was general agreement that low pay was often associated with inadequate training and, indeed, that Britain is deeply inadequate in its provision of training in basic skills, especially to young people leaving full-time education at 16 . Several Commissioners were directly involved with training policy issues. It was also agreed that the National Minimum Wage should not act as a disincentive, and could act as a positive incentive, to the provision of training in basic 
skills at all ages. Particular thought was given to the women re-entering the labour force in part-time employment who make up a high proportion of the low paid. It was therefore agreed that a lower rate of the National Minimum Wage could be proposed, and that this less-than-full rate, called a Development Rate, would apply to all 18 to 20 year olds, and also to workers over 20 on accredited training courses for the first six months in a new job with a new employer. The Government was to accept the formula, but has, up to the time of writing, remained adamant that the cut-off age should be the $22^{\text {nd }}$, and not the recommended, and more customary, $21^{\text {st }}$ birthday. It should be noted that, in practice, there has been little use of the Development Rate for over 21 year olds. That probably partly reflects a paucity of relevant accredited training schemes.

The question that has dominated popular attention has, understandably, been that of the level of the full National Minimum Wage rate. It was noted earlier that the Commission resolved this by a round-the-table bargain, but it was an unusual bargain. For a start, the Commissioners were agreed that they would approach it by what they came to refer to as 'triangulation'. That is, they would take into account a number of different pointers to the appropriate level, and test and discuss each one in turn. These included international comparisons of established minimum wage rates, measured in various ways. What, for example, was a reasonable 'bite', or proportion of the workforce to be directly affected? What percentage of the median wage was characteristic of minimum wages in other countries? How rapidly might a plausible percentage be approached? What has been happening, and can be expected to happen, to the shape of the UK's earnings distribution? Where would Wages Council rates have arrived at if they had not been abolished in 1993 ?

Effective use of these pointers relied upon good information on the present earnings distribution, and it is a reasonable question whether the Commission's recommendation on the initial level of the National Minimum Wage would have been different if they had known in 1998 what they were to come to learn by 2001 about the problems of the national earnings statistics. Speculation is of little value, but it is arguable that it would have made little difference. This is partly because some Commissioners were less 
impressed than others by statistical wizardry. Most had substantial bargaining experience and had acquired the scepticism that brings. But probably more important was that Commissioners were acutely aware of what they had learned, very tangibly through the consultative process, about what was being paid and what it was judged different sorts of firms could live with. The written evidence from different interest groups and the consultation visits both contributed substantially to the final decision on the rate.

An issue almost as important for many economists as the level of the Minimum Wage rate was the extent to which pushing up the floor of the national wage structure with a minimum would set off shock waves and knock-on effects, raising wages far above those of the low paid for whom the exercise was designed. Some macro-economic models that assumed substantial resilience of pay differentials produced hair-raising predictions of inflationary effects and consequent increased unemployment. The more the Commission investigated this, the less it bothered them. The vast majority of those likely to be affected by the National Minimum Wage were in non-unionised organisations, so trade union pressure was unlikely to be an issue. Affected firms were typically either very small, or characterised by flat hierarchies. Visits suggested that employers who had to raise the rates of their lowly paid employees might also think it sensible to add a little, less than pro rata, to their supervisors' pay, but they saw no reason to do anything higher up than that. On this, as on many other aspects of predicting the impact of the Wage, in the end the only thing to do was to wait and see what happened.

\section{After implementation}

One of the attractions of recommending the first week in April 1999 as the appropriate date for the introduction of the National Minimum Wage was that the annual New Earnings Survey was due the week afterwards. The immediate impact of the legislation on earnings would be captured with remarkable accuracy. It need hardly be said that the Commissioners awaited the early results of this, and of the Labour Force Survey, and of a battery of other economic indicators, with considerable interest. Were their recommendations well-informed, or would there be widespread non-compliance, a wave of lay-offs, or an inflationary surge? 
The National Minimum Wage was born at a very propitious economic juncture. Inflation was low, unemployment was low, and the economy was growing at a historically high rate. The larger of the sectors most affected by the Wage, such as retail, hospitality, and business services, were booming. During the rest of 1999 and over the following year, it gradually emerged that the best hopes for the Wage were being fulfilled. There was widespread awareness of it, and apparently substantial compliance with it, and the enforcement mechanism appeared to be active and effective (Inland Revenue/DTI, 2001). Whatever the number of the beneficiaries, it was substantial, and their earnings had increased by an initial surge of on average of over twenty per cent. But there had been minimal knock-on up the pay structure through restoration of differentials - it was negligible above the fifth percentile. There was no perceptible overall increase in prices, even at sectoral level. Nor was there evidence of adverse employment effects. Unemployment continued to fall, and labour force participation increased, most notably for 18 to 21 year olds (LPC, 2000a; 2001a). The fortunate timing of the birth of National Minimum Wage has helped it to develop into a healthy baby.

With the National Minimum Wage firmly established, the Commissioners turned their attention improving compliance and establishing principles for its periodic uprating. They proposed, in a Report published after the 2001 General Election, a biennial procedure, avoiding crude indexing formulae, but continuing the successful practices of widespread consultation and careful research (LPC, 2001b). As an exercise in social partnership, the Commission appears so far to have been successful, helped no doubt by the fact that it was dealing with a single issue. Its future success is likely to be judged by how astutely it can meet the challenges of a rapidly changing labour market, and in particular how it will cope with economic down-turns. It will also be judged by whether the National Minimum Wage will continue, as it has with so little controversy begun, to achieve improvements in the relative position of low paid workers. 


\section{$\underline{\text { References }}$}

Bain, G. 1999, 'The National Minimum Wage: further reflections', Employee Relations, $21: 1,15-28$.

Inland Revenue/DTI, 2001, The National Minimum Wage: Annual Report 2000 - 2001.

Low Pay Commission, 1998, The National Minimum Wage: First Report of the Low Pay Commission, Cm 3976, London: The Stationery Office.

Low Pay Commission, 1999, Developing Official Data on Low Pay, Occasional Paper 1, London: Low Pay Commission.

Low Pay Commission, 2000a, The National Minimum Wage: The Story So Far; Second Report of the Low Pay Commission, Cm 4571, London: The Stationery Office.

Low Pay Commission, 2000b, International Symposium, Occasional Paper 4, London: Low Pay Commission.

Low Pay Commission, 2001a, The National Minimum Wage: Making a Difference, Third Report of the Low Pay Commission, Volume One, Cm 5075, London: The Stationery Office.

Low Pay Commission, 2001b, The National Minimum Wage: Making a Difference: The Next Steps, Third Report of the Low Pay Commission, Volume Two, Cm 5175, London: The Stationery Office.

Metcalf, D. 1999a, 'The British National Minimum Wage', British Journal of Industrial Relations, 37:2, 172 - 201.

Metcalf, D. 1999b, 'The Low Pay Commission and the National Minimum Wage', Economic Journal, 109 (453), 46 - 66.

Office for National Statistics, 1998, 'Towards reconciliation of NES and LFS earnings data', Labour Market Trends, May, 223 - 231.

Office for National Statistics, 2002, 'NSQR Series Report No.11: Quality Review of the Framework for Labour Market Statistics'. 
Employee Relations Journal Vol 24 (6) - Employment Relations Public Policy Developments under the Labour Government (1997-2001) 